\title{
Increase in Leverage Driven by International Financial Reporting Standards Adoption
}

\author{
Incremento na Alavancagem Impulsionado pela Adoção do Padrão \\ Internacional Contábil
}

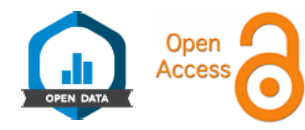

Pâmela Amado Tristão ${ }^{10}$ Igor Bernardi Sonza ${ }^{2}$

\section{ABSTRACT}

Context: adoption of International Financial Reporting Standards (IFRS) in Brazil has improved corporate governance practices and information available to investors, providing greater transparency. Despite its mandatory effect, companies listed in B3 tiers (Novo Mercado and Level 2) were already accustomed to using it, allowing a comparison with firms affected by the law. Objective: analyze the influence of IFRS adoption on the capital structure of publicly traded Brazilian companies by comparing firms that only began to adhere to it by the new law (Regular and Level 1) with firms that adopted IFRS before it went into effect (Novo Mercado and Level 2). Method: we performed a quasi-experimental design via difference-indifference (DID) estimator to compare leverage levels of firms segmented in treatment and control groups before and after IFRS. Conclusions: we found that the treatment group companies had higher market leverage after IFRS adoption, influenced by the greater information disclosure and, consequently, reduction of investors' perception of risk. In addition, the differences between groups in DID analysis were influenced by the greater effect on market leverage for treated companies and on net indebtedness for the control ones. Furthermore, we confirmed the pecking order theory assumptions for most of the covariates.

Keywords: capital structure; international accounting standards; B3 listing tiers.

\footnotetext{
1. Universidade Federal do Rio Grande, Instituto de Ciências Econômicas, Administrativas e Contábeis, Rio Grande, RS, Brazi

2. Universidade Federal de Santa Maria, Centro de Ciências Sociais e Humanas, Departamento de Ciências Administrativas, Santa Maria, RS, Brazi.
}

Cite as: Tristão, P. A., \& Sonza, I. B. (2021). Increase in leverage driven by international financial reporting standards adoption. Revista de Administração Contemporânea, 25(4), e200157. https://doi.org/10.1590/1982-7849rac2021 200157.en

\# of invited reviewers until the decision:
$1^{\text {st }}$ round
$2^{\text {nd }}$ round
$3^{\text {rd }}$ round
$4^{\text {th }}$ round
$5^{\text {th }}$ round

\section{RESUMO}

Contexto: a adoção das Normas Internacionais Contábeis (IFRS) no Brasil aprimorou as práticas de governança corporativa e informaçóes disponíveis para investidores, proporcionando maior transparência. Apesar de seu efeito obrigatório, empresas listadas nos segmentos da B3 (Novo Mercado e Nível 2) já estavam ajustadas nesse padrão, permitindo sua comparação com empresas afetadas pela lei. Objetivo: analisar influência da adoção das IFRS na estrutura de capital das empresas de capital aberto brasileiras comparando empresas afetadas pela lei (Regular e Nível 1) com as já adequadas ao padrão internacional (Novo Mercado e Nível 2). Método: realizamos um estudo quase-experimental pela estimaçáo do modelo Diferenças em Diferenças (DID) para comparar os níveis de alavancagem das empresas antes e depois das IFRS. Conclusóes: identificamos que as empresas tratadas tiveram maior alavancagem de mercado após a adoçáo do IFRS, influenciadas pela maior divulgação de informaçóes e, consequentemente, menor percepçáo de risco dos investidores. A estimaçáo do modelo DID evidenciou que as diferenças obtidas foram influenciadas pelo maior efeito na alavancagem de mercado para as empresas tratadas e na dívida líquida para as empresas de controle. As premissas da teoria do pecking order foram confirmadas para a maioria das variáveis de controle.

Palavras-chave: estrutura de capital; normas internacionais de contabilidade; segmentos especiais da B3.

JEL Code: G32, M41, B23.

Editor-in-chief: Wesley Mendes-Da-Silva (Fundação Getulio Vargas, EAESP, Brazil) (1) Reviewers: Daniel Vancin (Universidade do Vale do Rio dos Sinos, Brazill) Rafael Schiozer (Fundação Getulio Vargas, EAESP, Brazil) Peer Review Report: The disclosure of the Peer Review Report was not authorized by its reviewers.

Received: May 27, 2020 Last version received: September 28,2020 Accepted: September 29, 2020 


\section{INTRODUCTION}

Decision-making related to firms' long-term financing began with Modigliani and Miller (1958) (M\&M) in 1958 , who stated that capital structure was irrelevant in terms of companies' value in a perfect capital market context. Subsequently, other studies identified factors that influenced companies' use of equity or third party capital to finance their projects, such as trade off and pecking order theories (Myers \& Majluf, 1984; Myers, 1984). The assumptions of these theories take into consideration the origin of funds, as well as costs related to their use, which not only inform the market about their financing policy, but also make them susceptible to shareholder and stakeholder evaluations, influenced by the probability of income from investment and expropriation risk.

The regulatory environment in which companies operate also contributes to the equity or third party capital used and the access to it. In the Brazilian stock market, publicly traded companies faced a noticeable change at the end of the 2000s: the mandatory adoption of International Financial Reporting Standards (IFRS) established by Law No. 11,638 , in 2007 . While this adoption began in 2008, it was only complete in 2010. The adaptations involved were expected to provide higher predictive capacity of accounting information and improve aspects associated with information disclosure by implementing more demanding accounting and market-oriented principles (Moura \& Coelho, 2016), providing more effective enforcement of regulatory bodies, investor protection, corporate governance, and earning management (Silva \& Nardi, 2017).

Apart from these benefits, improvements in disclosure information can be associated to capital access, especially in an emerging market, like Brazil, as lower information asymmetry reduces investors' risk perception, leading companies to raise capital at lower costs. This leads to the hypothesis that mandatory adoption of IFRS changed companies' capital structure.

Despite its mandatory effect, forcing the majority of firms to adopt IFRS for the first time, companies in the B3 (Bolsa, Brasil, Balcáo) Level 2 and Novo Mercado tiers already adhered to them, because of the requirement to adopt IAS/IFRS since 2000. The three special listing tiers (Level 1, Level 2, and Novo Mercado) were created to fill in the information gap regarding publicly traded Brazilian companies and the increasing demand for information from investors. They created an opportunity to compare the different groups: firms that were affected by the law and those that were not affected, in order to investigate whether IFRS adoption could reduce the gap in access to capital.

Our paper focuses on the effect of IFRS adoption on firms' use of debt, aiming to analyze the influence of
IFRS adoption on the capital structure of publicly traded Brazilian companies by comparing firms that adhered to it when the law was established (Regular level and Level 1) and firms that already adopted it before the law (Novo Mercado and Level 2).

Our study contributes to the literature in at least three ways. First, while most studies associate the mandatory IFRS with improvements in accountability, compliance, and disclosure (Cova, 2008), best corporate governance practices (Lourenço \& Branco, 2015), ownership and control structures (Correia, Costa, \& Lucena, 2017), and tax avoidance (Braga, 2017), our paper, on the other hand, sheds light on changes in indebtedness level due to IFRS adoption. Second, accounting standards in Brazil have historically aimed to disclose information primarily to the government, whereas international standards focus on the figure of investors as their main users (Ghio \& Verona, 2015). In this process, the access to capital for Brazilian companies can be facilitated, as IFRS adoption aims to mitigate problems related to asymmetric information, reducing investors' risk perception. Third, the literature has provided more studies on developed markets, showing improvements in the information in countries where adequate levels of legal enforcement and investor protection have been identified. Therefore, it is also important to study the transition to IFRS in less developed markets, like Brazil, which face severe problems of access to capital (La Porta, Lopez-de-Silanes, \& Shleifer, 1999).

To conduct our study, we focused on the adoption of IFRS in a quasi-natural experimental model, as its imposition produced an exogenous shock. To isolate the effect of IFRS on debt financing policy from other shocks, we selected a treatment group (companies affected by the law - Regular and Level 1 tiers) and a control group (companies not affected by the law - Novo Mercado and Level 2). To conduct the quasi-natural experiment, we applied the difference-in-difference approach, which accounts for unobservable time effects, reducing the biases when selecting the sample. The adoption of an exogenous measure makes it possible to carry out a quasi-natural experiment, exploring its impact on financing policy changes (Arping \& Sautner, 2010). Under this approach, the IFRS law is the event used to test its effect on debt.

Our main results suggest that IFRS adoption changed treated firms' financing policy, increasing leverage in market measures (TML and LTML). This indicates that more severe compliance rules, as supposed a priori, reduce problems related to risk perception and increase access to credit. In addition, although both groups had their leverage levels affected by the shock, the difference-in-difference estimator was significant for market leverage and net indebtedness, being the market leverage influenced by the 
effect of treated companies (Regular and Level 1 tiers) and the indebtedness by the effect of control companies (Novo Mercado and Level 2 tiers). This result may be explained by the fact that companies that adhered to IFRS became more committed to following strict rules associated with better corporate governance practices, including information disclosure, which were better evaluated by the market. Furthermore, we confirmed the pecking order theory assumptions for most of the covariates.

We have also conducted robustness tests to check the model's internal validity and provide more evidence that capital structure of Brazilian firms was affected by the shock (IFRS adoption). Because one part of the period covered in our analysis coincides with the subprime financial crisis (2008-2010), this estimation became essential in our study. The placebo test results showed no statistically significant coefficients for DID, providing evidence that mandatory adoption of IFRS changed companies' financing polices, considerably reducing the subprime crisis effect in our analysis.

The remainder of this paper is organized as follows. Section 'The Capital Structure and IFRS Adoption' describes the relation between capital structure and IFRS. In the 'Method' section is shown the database, variables, and DID model. The effect of IFRS adoption on companies' capital structure is shown in the section afterwards. Finally, we present the concluding remarks in last section.

\section{THE CAPITAL STRUCTURE AND IFRS ADOPTION}

The study of firm capital structure started with Modigliani and Miller (1958), who claimed there is no optimal capital structure, because if firms keep free cash flow distribution constant, the financing policy chosen would be irrelevant.

Subsequent studies have focused on the relevance of other determinants of companies' financing structures. The combination of tax savings obtained through the use of debt, as well as the costs of bankruptcies associated with indebtedness, gave rise to one of the most important theories of capital structure, the trade-off. For Kraus and Litzenberger (1973), this theory is justified by the fact that "corporate taxation and the existence of bankruptcy costs can be considered market imperfections directly related to the evaluation of capital structure in a firm" (Kraus \& Litzenberger, 1973, p. 911). According to its presumptions, the financial leverage would reduce the liability of the interest rate and increase its profits after tax. Kraus and Litzenberger (1973) support the idea that the gain obtained by the use of debt through tax deduction could be determinant for the financing policy used, which also determines bankruptcy costs. So, the capital structure, in this approach, is directly related to the level of debt used.

Another important approach, the pecking order theory, focuses on information disclosure and evaluation from external agents. External evaluation is the main aspect considered by the theory, which proposes that the company should follow a hierarchical order of financing preference. First, firms use internal resources (obtained from retained profits); second, if necessary, firms can use external sources (issuing debt), and as the last resource, stocks. In sum, firms should issue debt as a first external source and issue stock only if equity capital and debt issuance are not enough. According to Myers (1984), the preference for internal capital would reduce or extinguish problems related to adverse selection. Contrarily, by issuing stocks, the company could dilute stakeholder ownership and create problems related to differing information between internal and external agents, hindering the correct evaluation of company assets, which are then priced at an average value (Akerlof, 1970).

These seminal studies gave birth to the most important theories related to firm financing policy. Recent papers focused on capital structure behavior and factors that influence changes in debt ratio chosen by firms (Graham, Leary, \& Roberts, 2015). A set of studies on the leverage stability hypothesis present contradictory findings. Lemmon, Roberts, and Zender (2008) confirmed the stability hypothesis, showing that companies tend to keep their debt ratios for a long period, both for high and low leverage levels. DeAngelo and Roll (2015), adversely, showed unstable behavior.

Another research line focuses on regulatory environmental changes and legal enforcement required by the market as a way to change firms' financing policies. The mandatory adoption of International Accounting Standards Board (IASB), as one of these changes, aimed at the development of globally accepted accounting information disclosure standards. The adoption by Brazilian companies between 2007 and 2009, according to Brüggemann, Hitz, and Sellhorn (2013) and Pires and Decourt (2015), aimed to increase transparency, access to capital, and comparability of financial statements between heterogeneous companies in Brazil.

Although Daske, Hail, Leuz, and Verdi (2013) emphasize the institutional political environment and ownership control in countries as essential factors to explain benefits brought by the adoption of IFRS, there are notorious economic consequences of IFRS adoption in developed and undeveloped markets. The importance of Brazilian firms' convergence to IFRS is related to their participation in a global, comparable, and transparent information market, as Nnadi and Soobaroyen (2015) indicate that incentives for 
emerging countries lie in the greater attraction of foreign investment and participation on international exchange chains.

Santos, Fávero, and Distadio (2016) pointed out that the increase in accounting quality results had its benefits associated to greater liquidity with lower spread between the buying and selling and reduction of analysts forecast errors. In line with accounting information quality improvement, the impact of the international standard adoption is also related to capital cost reduction.

The access to capital would become less costly because higher quality information in company reports would lead to a reduction of informational asymmetry, affecting the equity capital through stock issuance, as external agents would price assets at better prices, and third party capital because companies would contract less costly debt. This adjustment is important as investors and creditors have different demands regarding the quality of disclosed information (Marques, Nakao, \& Costa, 2017).

Studies focusing on how IFRS change capital costs have shown contradicting results, probably explained by different environments in which companies operate. $\mathrm{Li}$ (2010) found equity capital cost reduction in companies listed in European capital markets. However, Moscariello, Skerratt, and Pizzo (2014) found no impact on cost of debt for UK and Italian firms.

The inverse relationship between IFRS adoption and cost of debt has also been reported in the empirical literature. Lee, Walker, and Christensen (2010) associated IFRS adoption with reduction in capital costs. Daske et al. (2013)found capital cost reduction in a sample of over 30 counties with voluntary and mandatory IFRS adoption. Santos et al. (2016), in a sample of companies from 145 emerging countries from 2004 to 2014, including Brazil, found that financial decisions are influenced by IFRS behavior, in which size and working capital management presented a negative relationship between IFRS and indebtedness.

Papers focusing on the Brazilian market follow similar patterns. Silva and Nardi (2014) reported a small reduction in equity costs of Brazilian companies after IFRS adoption. Gatsios, Silva, Ambrozini, Assaf Neto, and Lima (2016) found that IFRS did not significantly contribute to reduction of equity costs in Brazilian companies. Moura and Coelho (2016) identified significant changes in debt ratio behavior when studying a sample of 87 Brazilian companies from 1995 to 2002, and associated their results to changes in the treatment of leasing in the new accounting standards, which affect total assets and their representation of indebtedness.
The relationship between IFRS adoption and capital cost is directly related to firms' capital structure. Naranjo, Saavedra, and Verdi (2014) found that IFRS adopters with high debt capacities chose debt as their primary source of external financing, as firms with better reporting quality likely have better access to public, rather than private, debt, opposing the pecking order theory proposed by Myers and Majluf (1984).

Based on the assumption that adoption of IFRS leads to an increase in disclosure, which is expected to mitigate the risk of investors, reducing the debt costs and changing companies' financing policies, we tested the following hypotheses:

Hypothesis 1: The mandatory adoption of IFRS changed firms' capital structure if compared to the period before this implementation.

Hypothesis 2: The adoption of the international disclosure standard reduced the gap of access to capital between firms affected by the law and companies already adopting IFRS previously.

\section{METHOD}

In this section, we describe our data, the quasinatural experiment, and the variables used. Our sample covers B3 (Bolsa, Brasil, Balcão) publicly traded Brazilian firms, based on information from 2007 to 2012, divided in two parts, before the full adoption (2007-2009) and after it (2010-2012). The data were obtained by Economática (companies' balance sheets and income statements) and by CVM's Reference Forms.

We excluded observations using the following filters: (a) companies listed in financial and security sectors; (b) companies without information for at least two years before and after the shock; and (c) dual-listing companies with American Depositary Receipts (ADRs) listed in Regular level or Level 1 tiers. To control the influence of outliers, variables were winsorized in each tail at a level of 5\% and performed using Stata SE software.

The aim of the study is to test whether firms changed their financing policies after IFRS took effect in Brazil performing an estimation through a quasi-natural experiment. The estimation imposes the comparison of treatment (companies affected by the Law No. 11,638 Regular and Level 1 tiers) and control (those not affected by the Law No. 11,638 — Novo Mercado and Level 2 tiers) groups. To make the comparison possible, we used the difference-in-difference (DID) approach, commonly used when causal relationships are established in a quasi-natural experiment, where the effects of an event on groups affected 
by a given intervention are compared with those that have not been affected (Vig, 2013).

The choice for studying IFRS adoption in our experiment is based on Roberts and Whited (2013) argument that this model estimation is adequate to analyze effects of changes due to the economic, political, or institutional environment. According to Meyer (1995), this method has potential to overcome problems related to heterogeneity. Furthermore, DID estimation can achieve unbiased results, while explaining the unobserved time invariant heterogeneity (Villa, 2016).

To identify a group containing firm characteristics similar to those that suffered changes from this law, Funchal and Monte-Mor (2016) suggest the use of propensity score match (PSM). This procedure isolates treated observations and finds an observation from the control group that matches the treated observation in several dimensions. By using the kernel PSM, as suggested by Leuven and Sianesi (2014), we could find a similar control company for each firm affected by the law.

We estimated the DID with PSM by creating two main variables in our model. The first, called 'post,' is an exogenous event (shock), which, in our case, is the implementation of Law No. 11,638 in 2007, related to IFRS adoption, whose deadline for the adaptation of companies was 2009. Due to this fact, our sample considered the three years before this mandatory standardization (2007-2009), in which the value ' 0 ' was assigned, and three years after this shock (2010-2012), in which the value ' 1 ' was assigned.

The other variable created, called 'treated,' refers to the treatment and control groups. For the treatment, we considered firms that belonged to Regular level and Level 1 of the B3 listing tiers - companies that, until the implementation of the IFRS law, did not need to comply with international accounting standards; for these companies, the value ' 1 ' was assigned. The control group was formed by Level 2 and Novo Mercado companies, as these, even before the law was implemented, had already adopted international accounting standards, because it is a requirement to belong to these B3 listing tiers. For these companies, the value ' 0 ' was assigned. The interaction of these two variables, post and treated, generated the DID variable, shown in Equation (1).

$Y_{i t}=\delta_{0}+\delta_{1} \cdot$ post $_{t}+\delta_{2} \cdot$ treated $_{i}+\delta_{3} \cdot\left(\right.$ treated $_{i} \times$ post $\left._{t}\right)+\varepsilon_{i t}$

where $i$ represents the company; $t$ the time; $Y_{i t}$ the dependent variable; $\delta$, captures aggregate factors that would cause changes in $Y$ over time, even in the absence of a policy change; $\delta_{2}$ captures possible differences between the treatment and control groups before the change (shock); $\delta_{3}$ represents the coefficient of interest and $\varepsilon_{\text {it }}$ the error parameter. We calculated this coefficient by the difference between the treated group before and after the event minus the difference between the control group before and after the event, as shown in Equation (2).

$\hat{\delta}_{3}=\left(\hat{y}_{(\text {treat }, \text { post }=1)}-\hat{y}_{(\text {treat }, \text { post }=0)}\right)-\left(\hat{y}_{(\text {control }, \text { post }=1)}-\hat{y}_{(\text {control }, \text { post }=0)}\right)$

In addition to the matching estimator, we ran an ordinary least square (OLS) regression to identify the effect of a set of control variables on the dependent variables. We estimated this model for two reasons: first, it enables us to capture the heterogeneous effect of IFRS on firms' capital structure, and second, it allows us to check our results' robustness.

Table 1. Dependent variables.

\begin{tabular}{|c|c|c|c|}
\hline Variable & Code & Measure & Previous studies \\
\hline Total market leverage & TML & $\begin{array}{c}\text { (current liabilities + non-current liabilities) / } \\
\text { market value of assets }\end{array}$ & $\begin{array}{l}\text { Frank and Goyal (2009); Lemmon et al. (2008); } \\
\text { Rajan and Zingales (1995) }\end{array}$ \\
\hline Total book leverage & TBL & $\begin{array}{l}\text { (current liabilities }+ \text { non-current liabilities) / } \\
\text { book value of assets }\end{array}$ & $\begin{array}{l}\text { Frank and Goyal (2009); Lemmon et al. (2008); } \\
\text { Rajan and Zingales (1995) }\end{array}$ \\
\hline Long-term market leverage & LTML & (non-current liabilities / market value of assets) & Frank and Goyal (2009); Lemmon et al. (2008) \\
\hline Long-term book leverage & LTBL & (non-current liabilities / book value of assets) & Frank and Goyal (2009); Lemmon et al. (2008) \\
\hline Net indebtedness & NI & $\begin{array}{c}\text { (current liabilities + non-current liabilities) - } \\
\text { cash available / total assets }\end{array}$ & DeAngelo and Roll (2015); Lemmon et al. (2008) \\
\hline
\end{tabular}

Note. Market value of assets is the stock price multiplied by the number of shares outstanding. Source: elaborated by the authors. 
The inclusion of covariates in the DID model brings gains in efficiency, adjusting it for conditional randomization and reducing the error variance (Roberts \& Whited, 2013). We present this model in Equation (3).

$$
Y_{i g t}=\alpha+\delta_{3} \cdot\left(\text { treated }_{i} \times \text { post }_{t}\right)+\beta \cdot X_{i g t}+\gamma_{g}+\lambda_{t}+\varepsilon_{i t}
$$

where $i$ refers to the company; $g$ to the period; $t$ to the segment; $\mathrm{Y}_{\mathrm{igt}}$ to the dependent variable; $\delta_{3}$ to the DID estimator;
$\mathrm{X}_{\mathrm{igt}}$ to the vector of control variables (size, profitability, tangibility, growth and investment opportunities, risk, corporate governance practices, and tax benefits); $\gamma_{\mathrm{g}}$ and $\lambda_{\mathrm{t}}$ indicate the sector fixed effects and time fixed effects; finally, $\varepsilon_{\mathrm{it}}$ is the error parameter. Leverage, in our study, is measured by five dependent variables, shown in Table 1. Additionally, we included covariates in our OLS estimations, shown in Table 2.

Table 2. Covariates.

\begin{tabular}{|c|c|c|c|}
\hline Variable and code & Measure & Previous studies & Signal \\
\hline \multicolumn{4}{|c|}{ Panel A: Profitability } \\
\hline Return on equity (ROE) & Net profit / Equity & $\begin{array}{c}\text { Frank and Goyal (2009); Graham, Leary, and Roberts (2015); } \\
\text { Lemmon et al. (2008) }\end{array}$ & Neg./Pos. \\
\hline Free cash flow (FCL) & {$[$ EBIT $\times(1-$ Tax $)+$ Depreciation - Capex $] /$ Total assets } & Lemmon et al. (2008) & Neg./Pos. \\
\hline \multicolumn{4}{|c|}{ Panel B: Firm size } \\
\hline Total assets (TA) & Log of assets & $\begin{array}{l}\text { Devos, Rahman, and Tsang (2017); Frank and Goyal (2009); } \\
\text { Lemmon et al. (2008) }\end{array}$ & Neg./Pos. \\
\hline Equity (PL) & Log of equity & Sonza and Kloeckner (2014) & Neg./Pos. \\
\hline Net sales (R) & Log of net sales & $\begin{array}{l}\text { DeAngelo and Roll (2015); Devos et al. (2017); Frank and Goyal } \\
\text { (2009); Graham et al. (2015); Rajan and Zingales (1995) }\end{array}$ & Neg./Pos. \\
\hline \multicolumn{4}{|c|}{ Panel C: Growth opportunities } \\
\hline Change in log assets (LMA) & $\log$ of total assets - Log of total assets ${ }_{t-1}$ & Frank and Goyal (2009) & Neg./Pos. \\
\hline Capex (CAP) & Capital expenditure / Total assets & $\begin{array}{c}\text { Axelson, Jenkinson, Strömberg, and Weisbach (2013); Frank and } \\
\text { Goyal (2009); Locan and Caldeira (2014) }\end{array}$ & Neg./Pos. \\
\hline \multicolumn{4}{|c|}{ Panel D: Investment opportunities } \\
\hline Tobin’s Q (Q) & $(\mathrm{MVE}+\mathrm{PS}+\mathrm{D})^{1} /$ Total assets & Catapan and Colauto (2015) & Neg. \\
\hline \multicolumn{4}{|c|}{ Panel E: Nature of assets } \\
\hline Tangibility (TAN) & (Inventories + Fixed assets) / Total assets & $\begin{array}{l}\text { DeAngelo and Roll (2015); Graham et al. (2015); Kieschnick } \\
\text { and Moussawi (2018); Lemmon et al. (2008); Tarantin and Valle } \\
\text { (2015) }\end{array}$ & Neg./Pos. \\
\hline \multicolumn{4}{|c|}{ Panel F: Risk } \\
\hline Beta- systematic risk $(\mathrm{SR})^{2}$ & $\mathrm{R}_{\mathrm{t}}=\alpha+\beta \mathrm{R}_{\mathrm{M}, \mathrm{t}}+\varepsilon_{\mathrm{t}}$ & Scholtz (2014); Vancin, Kirch, Perlin and Mastella (2009) & Pos. \\
\hline \multicolumn{4}{|c|}{ Panel G: Tax } \\
\hline Tax benefits (BF) & (Income tax $\times$ Financial expenditure) / Total assets & Frank and Goyal (2009); Lemmon et al. (2008) & Pos. \\
\hline \multicolumn{4}{|c|}{ Panel H: Corporate governance } \\
\hline $\begin{array}{l}\text { Ownership structure of the } \\
\text { major shareholder (APC) }\end{array}$ & $\%$ of voting share held by the major shareholder & Colombo and Caldeira (2018); Sonza and Kloeckner (2014) & Neg./Pos. \\
\hline $\begin{array}{l}\text { Ownership structure of the } \\
\text { three principal shareholder } \\
\text { (TPAC) }\end{array}$ & $\begin{array}{l}\% \text { of voting share held by the three principal } \\
\text { shareholder }\end{array}$ & Colombo and Caldeira (2018); Sonza and Kloeckner (2014) & Neg./Pos. \\
\hline $\begin{array}{l}\text { Ownership structure of the } \\
\text { five principal shareholder } \\
\text { (CPAC) }\end{array}$ & $\begin{array}{c}\% \text { of voting share held by the five principal } \\
\text { shareholder }\end{array}$ & Colombo and Caldeira (2018); Sonza and Kloeckner (2014) & Neg./Pos. \\
\hline \multicolumn{4}{|c|}{ Dummies } \\
\hline $\begin{array}{l}\text { Sector fixed effect (Sector } \\
\text { FE) }\end{array}$ & Dummies: 1 for sector firms, 0 otherwise & Sonza and Kloeckner (2014) & - \\
\hline Time fixed effects (Time FE) & Dummies: 1 for allocated time, 0 otherwise & Sonza and Kloeckner (2014) & - \\
\hline
\end{tabular}

Note. ${ }^{1}$ Suggested by Chung and Pruitt (1994), where market value is the sum of MVE minus firm's stock price multiplied by the number of common shares outstanding, PS minus settlement value of preferred shares outstanding, and D minus total debt (current liabilities minus current assets plus inventories and long-term debt). ${ }^{2}$ Is the coefficient on the stock market portfolio from a market model regression. Each beta is calculated yearly with the monthly stock return regressions. Source: elaborated by the authors. 
We also conducted the placebo test to check internal validity, which is important when estimating models with DID due its untestable key assumption estimator — parallel trends (Roberts \& Whited, 2013). In sum, we assume that the shock falsely occurs in 2014 to verify if the results are not driven by some unobservable characteristics that could influence the interest variables.

\section{ANALYSIS OF RESULTS}

We start this section by presenting the descriptive statistics of dependent variables (shown in Table 3), where the sample was divided into treated and control groups in two periods, covering information from 2007-2012, to compare companies before and after the shock in order to estimate its impact on companies' leverage.

The descriptive statistics show significant changes in leverage measures for companies affected by IFRS. Market measures increased significantly when comparing the periods before and after the shock. The average TML in treatment companies increased from $1.15 \%$ to $2.67 \%$, while LTML from $0.57 \%$ to $1.32 \%$. LTBL underwent a small change. Our results also show that, although control companies used more debt after 2010, this growth was found to be less significant when compared to the treated group.

Table 3. Descriptive statistics for dependent variables.

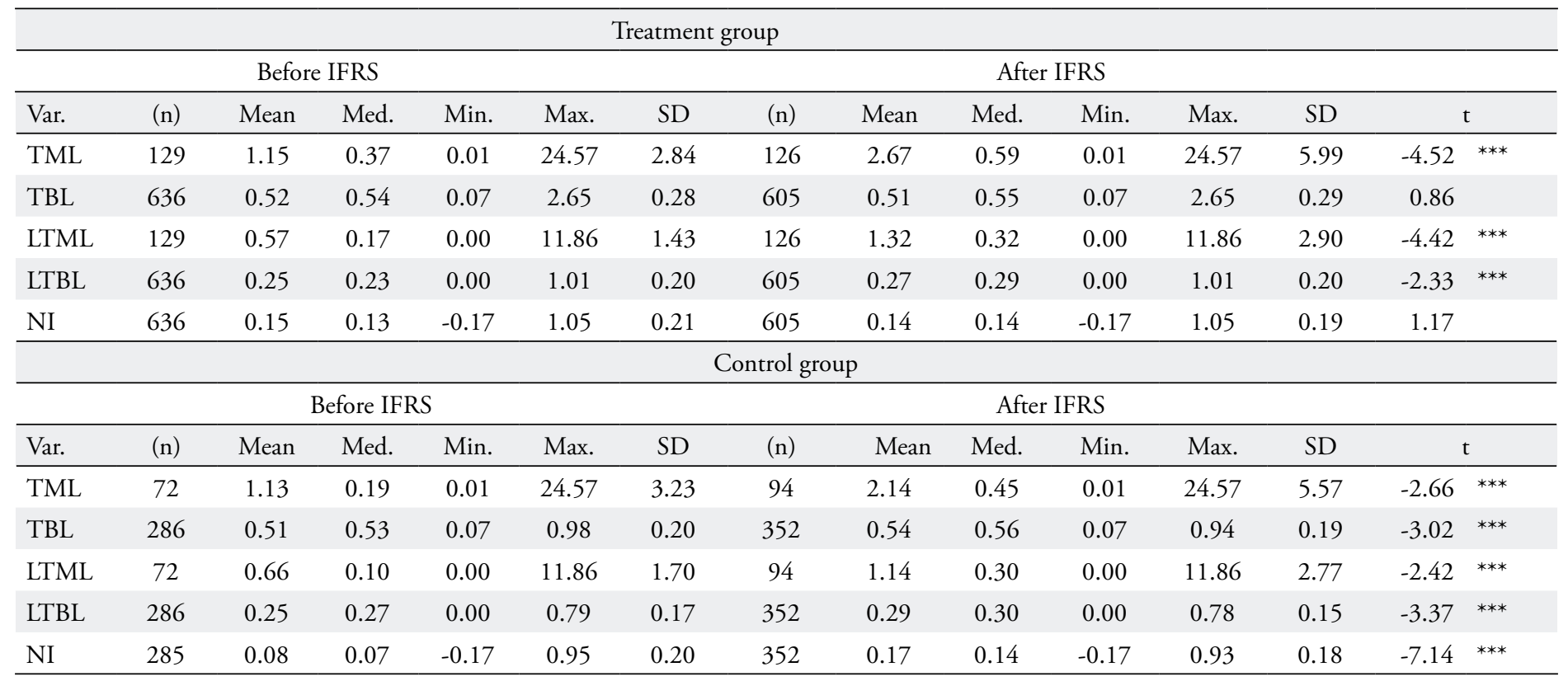

Note. Treated group is formed by companies affected by IFRS and control group by companies not affected by IFRS in the sample. In the header, Var. indicates the variables; $\mathrm{n}$ is the number of observations; Mean is the average value; Med. indicates the Median; Min. and Max. represent the minimum and maximum values; SD expresses the standard deviation; and $t$ represents the $t$-test. In the first column, TML is the total market leverage; TBL is the total book leverage; LTML is the long-term market leverage; LTBL is the long-term book leverage; and NI is the net indebtedness. The symbol *** indicates statistical significance at $1 \%$. Source: elaborated by the authors.

These results support the idea that, by using international compliance rules, companies face fewer difficulties to access credit, specifically those affected by the mandatory IFRS. In other words, this finding supports our first hypothesis, which states that companies are affected by the mandatory IFRS debt financing policy. Supporting this finding, Silva and Nardi (2014) emphasize the increase in efficiency of contracting in debt markets, with potential gains for equity investors in terms of reduced cost of debt capital.

Appendix 1 presents the descriptive statistics of covariates in our model. There are no noticeable changes in significance for treated and control groups before and after the IFRS adoption, except for size measures (TA, PL, and R), Tobin's Q and LMA, whose differences become not significant in the treated group. However, $\mathrm{ROE}$ and $\mathrm{BF}$ showed significant growth after the adoption of IFRS for the control group and a significant decrease for the treatment group.

In corporate governance measures (APC, TAC, and CPAC), we identified a significant fall in both treated and control groups, which means that ownership concentration reduced after mandatory IFRS. This result was expected, as companies with better disclosure and lower asymmetric information problems tend to spread out control more widely. 
To identify highly correlated variables, we ran the correlation test, identifying the existence of collinearity between size measures (TA, PL, and R), profitability and tangible assets (FCL and TANG), and PL, LMA, and corporate governance variables (APC, TPAC, and CPAC). We also ran the variance inflation factor (VIF), confirming the collinearity between these variables. To avoid problems in the estimation, we withdrew TA, R, FCL, LMA, TPAC, and CPAC. After that, the VIF did not present value above 5 for any variable.

We start the discussion of DID model comparing treated and control companies' leverage graphically, shown in Figure 1. The graphs suggest that IFRS adoption considerably reduced the pre-existing valuation gap between firms affected by the law and those not affected by it. In market leverage, differences in TML and LTML between both groups reduced considerably after the shock, where treated companies presented higher dependency, as found by DeAngelo and Roll (2015) and Lemmon et al. (2008).

In accounting leverage (TBL, LTBL) and NI, the differences observed before 2010 are almost completely eliminated in the second period. Sampaio, Gallucci, Silva and Schiozer (2020) found similar results. These findings emphasize that mandatory IFRS reduced the discrepancies between Brazilian companies that, until then, had different levels of disclosure.
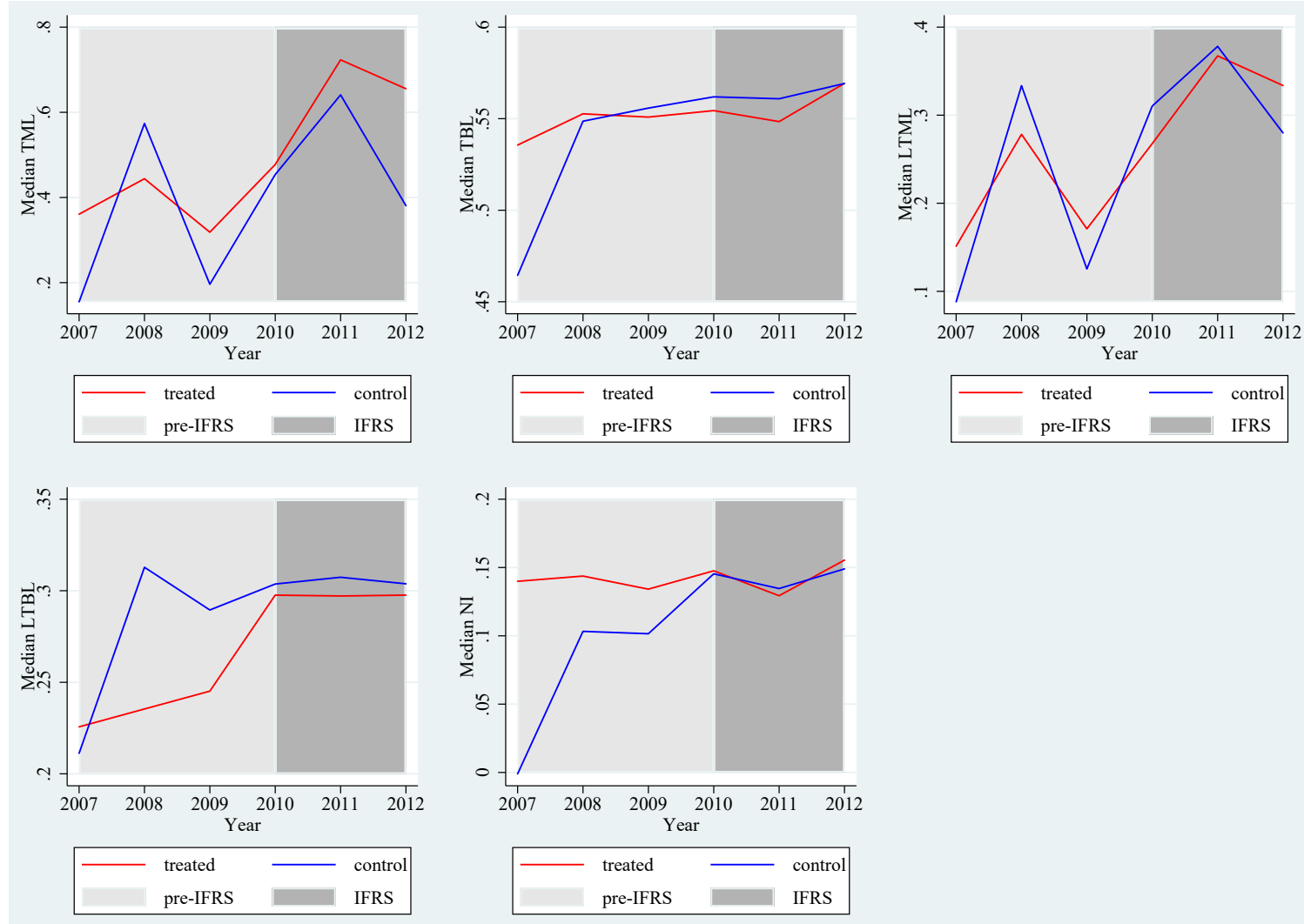

Figure 1. Leverage ratios graphical analysis.

The y-axes are composed by the median of the dependent variables: TML (total market leverage -47 treated and 66 control companies); TBL (total book leverage - 298 treated and 130 control companies), LTML (long-term market leverage - 47 treated and 66 control companies); LTBL (long-term book leverage - 283 treated and 126 control companies) and NI (net indebtedness - 271 treated and 116 control companies); and the $\mathrm{x}$-axes represent the years (between 2007 and 2012). The red line indicates the treated and the blue line represents the control companies; light gray represents the pre-IFRS period and dark gray the post-IFRS period. Source: elaborated by the authors.

We now examine debt financing policy behavior, comparing treated and control companies, before and after the shock by the kernel PSM (propensity score match) estimation, which creates an artificial comparison group, where, for each company in the treatment group, we found a company with similar characteristics in the control group. According to Gertler, Martinez, Premand, Rawlings, and Vermeersch (2016), this allows an identification of similar companies between both groups. The results are presented in Table 4. 
Table 4. Difference-in-difference matching estimation.

\begin{tabular}{|c|c|c|c|c|c|c|c|c|c|c|}
\hline & TML & $(\mathrm{n})$ & TBL & $(\mathrm{n})$ & LTML & $(\mathrm{n})$ & LTBL & (n) & NI & (n) \\
\hline \multicolumn{11}{|l|}{ Before } \\
\hline Treated & 0.080 & 46 & 0.540 & 46 & 0.034 & 46 & 0.232 & 46 & 0.226 & 46 \\
\hline Control & 0.121 & 30 & 0.483 & 30 & 0.082 & 30 & 0.277 & 30 & 0.082 & 30 \\
\hline Difference & -0.041 & & 0.057 & & -0.048 & & -0.045 & & $0.144^{* * *}$ & \\
\hline SD & $(0.095)$ & & $(0.060)$ & & $(0.047)$ & & $(0.042)$ & & $(0.040)$ & \\
\hline $\mathrm{t}$ & -0.43 & & 0.96 & & -1.03 & & -1.08 & & 3.59 & \\
\hline \multicolumn{11}{|l|}{ After } \\
\hline Treated & 0.268 & 126 & 0.516 & 605 & 0.132 & 126 & 0.279 & 605 & 0.148 & 605 \\
\hline Control & 0.071 & 42 & 0.552 & 42 & 0.043 & 42 & 0.347 & 42 & 0.131 & 42 \\
\hline Difference & $0.197^{* * *}$ & & -0.036 & & $0.089^{* *}$ & & $-0.069^{* *}$ & & 0.017 & \\
\hline SD & $(0.071)$ & & $(0.042)$ & & $(0.035)$ & & $(0.029)$ & & $(0.028)$ & \\
\hline $\mathrm{T}$ & 2.78 & & 0.85 & & 2.56 & & 2.34 & & 0.60 & \\
\hline DID & $0.238^{* *}$ & & -0.093 & & $0.138^{* *}$ & & -0.024 & & $-0.127^{* * *}$ & \\
\hline SD & $(0.119)$ & & $(0.073)$ & & $(0.058)$ & & $(0.051)$ & & $(0.049)$ & \\
\hline $\mathrm{T}$ & 2.01 & & 1.28 & & 2.36 & & 0.47 & & 2.59 & \\
\hline
\end{tabular}

Note. In the header, $\mathrm{n}$ is the number of observations; TML is the total market leverage; TBL is the total book leverage; LTML is the long-term market leverage; LTBL is the long-term book leverage; and NI is the net indebtedness. In the first column, DID is the difference-in-difference estimator; SD is the standard deviation; and t represents the t-test. The regressions were estimated using kernel propensity score matching. The results evidence statistically significant differences between treated and control groups for NI before IFRS adoption. After its adoption, statistically significant differences were found for market leverage (TML and LTML) and TLBL. The difference-in-difference estimator evidences positive differences for TML and LTML and negative differences for NI. The covariates used in the model are equity (PL), ownership structure of the major shareholder (APC), capex (CAP), tax benefits (BF), tangibility (TAN), beta (SR), and sector. Tobin's Q was used only in book leverage measures. Return on equity (ROE) was excluded in the model estimation because it reduced considerably the number of iterations. The symbols ${ }^{* *}$ and ${ }^{* * *}$ indicate statistical significance at $5 \%$ and $1 \%$, respectively. Source: elaborated by the authors.

By estimating the model, we identified significant debt differences in both groups. In the pre-IFRS period, net indebtedness was statistically different at the $1 \%$ level (0.144). After the shock, all measures, except LBL and NI, were statistically significant. The coefficients obtained for TML e LTML indicate that companies affected by IFRS started to use more market leverage and, for LTBL, indicates that companies that adhered previously to IFRS started to use higher leverage, evidencing differences between the effects of the treatment and control groups.

The DID estimator, the most important coefficient in our model, was statistically significant for market leverage, both total (TML) and long-term (LTML), as well as for net indebtedness (NI), with respective coefficients of 0.238 (TML), 0.138 (LTML), and -0.127 (NI), significant at the $5 \%, 5 \%$, and $1 \%$ level, confirming that companies differ in terms of leverage use.

Overall, the comparison of both groups before and after the shock allows some inferences. Observing the treated companies' dependency on market capital, we can argue that the reduction of asymmetric information and risk perception facilitated their access to capital, explained by the fact that access to markets with high legal protection is a way to signal commitment to corporate governance practices (Silva \& Nardi, 2017). These results are in line with Barth, Konchitchki, and Landsman (2013), who state that firms with more transparent earnings enjoy lower cost of capital, and with Florou and Kosi (2015), who affirm that higher debt levels are based on investors' trust in financial statement information.

Another possible explanation for the effect of IFRS on market leverage, rather than on book leverage, is that this shock does not affect decisions of managers with regards to leverage, as the change in market leverage is more passive on the side of the company. In other words, market leverage of treated companies differs in relation to the control group, mainly because the treated companies become more valorized, being less associated with the fact that managers actually decide to reduce leverage.

In this context, we can argue that, although the mandatory IFRS adoption reduced differences between the heterogeneous companies in the Brazilian stock market and access to capital, companies continue to differ in terms of book leverage after the law, not rejecting our second hypothesis completely, since companies really showed differences in terms of capital structure. Our findings are also associated with the heterogeneity of Brazilian traded companies; as up until 2009, companies could issue their 
reporting following the national accounting standards, which required less information than the international standards, adopted by companies in B3 listing tiers. Reinforcing this argument, Florou and Kosi (2015) affirm that, in countries with large differences between local generally accepted accounting principles (GAAP) and IFRS, the debt market benefits are concentrated.

The improvement in information disclosed by companies affected by the law, for Nakao and Gray (2018), may be consistent with a constant horizon time after its adoption. This means that the longer the period in which the companies affected by the law may disclose their information in accordance with the international standard, the smaller the differences between both groups. For Figlioli, Lemes, and Lima (2017), the Brazilian accounting standards, historically, were not geared to meet the demand for information by investors. Because of this, economic consequences arising from IFRS adoption may not be reflected in the short run.

As in our paper, we investigate the adoption of IFRS in a period immediately after its implementation; it may explain not statistically significant differences in accounting leverage measures. Gatsios et al. (2016) assert that the impact of IFRS is not only related to its adoption, but also to its use by companies and users, which requires a horizon of time to be found. Sampaio et al. (2020) studied the effect of IFRS on firm value, which showed a positive impact on Tobin's $Q$ and market-to-book ratios in lower governance tiers. Similar to our findings, their results show a substantial decrease in the valuation gap after IFRS.

Studies focused on different regulatory events in Brazil provide additional inferences for our findings. Analyzing a similar shock regarding corporate governance brought by the Sarbanes-Oxley Act (SOX), Funchal and Monte-Mor (2016) examined its effect on firms' debt financing using two sets of firms, one affected by SOX and another not affected. Their results indicated that firms affected by the law increased credit-asset ratio considerably when compared to the non-affected, especially for total credit, in the period after SOX went into effect for the treatment group.

We continue our analysis by estimating multivariate models and include a set of control variables. Table 5 presents the OLS estimation with covariates through the standard DID framework. In this model, we included sector and time fixed effects to control sectorial heterogeneity and aggregate economic shocks, respectively.

Similar to our estimation model (Table 4), DID coefficients were significantly positive for market leverage, confirming our previous findings. The systematic risk is positively associated to long-term book leverage, where a one-percentage point increase in beta increases LTBL by 0.04 percentage points, at $5 \%$ significance, like Scholtz (2014). Regarding the return on equity, a onepercentage point increase in ROE reduces TML and LTML by 0.44 and 0.18 percentage points, respectively (both at $1 \%$ significance). Similar to results reported by Lemmon et al. (2008), Tarantin and Valle (2015) and Graham et al. (2015).

The companies' size (PL) is statistically significant for market (TML and LTBL) and accounting measures (TBL and LTBL), showing significant and positive relationship, contradicting Campos and Nakamura (2015) and Kieschnick and Moussawi (2018). Tobin's Q, the investment opportunities' measure, showed negative relationship with book leverage. The coefficients -0.03 for both TBL and LTBL are statistically significant at 1\% level.

Capex, a proxy for growth opportunities, presented negative and statistically significant association with market leverages (total and long-term), as well as TBL and NI, different from the results of Locan and Caldeira (2014). Tax benefits were statistically significant for the five leverage measures. Specifically, in terms of market leverage, increase in tax benefits reduced TML and LTML by 0.04 and 0.02 percentage points, respectively. Similar coefficients were found for TBL, LTBL, and NI. Lastly, in terms of corporate governance proxies, the percentage of ordinary shares held by the major shareholder explain companies' book leverage. The results from the final stage of the analysis support the pecking order theory's assumptions of Myers and Majluf (1984) and Myers (1984), in which tangibility, capex, and tax benefits are considered the most relevant leverage variables.

The final step conducted consisted of a robustness test. In short, it was run to prove that IFRS adoption did affect the firms' capital structure changes. To conduct the placebo test, we replicated our DID analysis, changing the period of the shock to 2014, using a different time window (2011-2016), as shown in Table 6.

Our results showed no statistically significant DID for any of the leverage measures, suggesting our models' internal validity and providing more evidence that the IFRS adoption had an effect on the capital structure of Brazilian companies. Additionally, to test model validity, we also ran our DID model at $1 \%$ and $2.5 \%$ winsorization, which showed similar results. 
Table 5. OLS estimation with covariates.

\begin{tabular}{|c|c|c|c|c|c|}
\hline Variable & $\begin{array}{c}\text { TML } \\
(\mathrm{n}=185)\end{array}$ & $\begin{array}{c}\text { TBL } \\
(\mathrm{n}=185)\end{array}$ & $\begin{array}{c}\text { LTML } \\
(\mathrm{n}=185)\end{array}$ & $\begin{array}{c}\text { LTBL } \\
(\mathrm{n}=185) \\
\end{array}$ & $\begin{array}{c}\text { NI } \\
(\mathrm{n}=185)\end{array}$ \\
\hline DID & $0.14^{* *}$ & 0.07 & $0.07^{* *}$ & -0.03 & 0.05 \\
\hline SD & $(0.07)$ & $(0.04)$ & $(0.03)$ & $(0.02)$ & $(0.04)$ \\
\hline $\mathrm{t}$ & 2.05 & 1.61 & 2.06 & -1.26 & 1.14 \\
\hline SR & -0.03 & 0.03 & -0.01 & $0.04^{* *}$ & 0.00 \\
\hline SD & $(0.03)$ & $(0.02)$ & $(0.01)$ & $(0.01)$ & $(0.02)$ \\
\hline $\mathrm{t}$ & -1.14 & 1.53 & -0.86 & 2.24 & 0.44 \\
\hline $\mathrm{ROE}$ & $-0.44^{* * *}$ & 0.03 & $-0.18^{* * *}$ & 0.06 & -0.11 \\
\hline SD & $(0.15)$ & $(0.09)$ & $(0.06)$ & $(0.05)$ & $(0.07)$ \\
\hline $\mathrm{t}$ & -2.84 & 0.32 & -2.97 & 1.18 & -1.44 \\
\hline $\mathrm{PL}$ & $0.03^{* *}$ & $0.02^{* *}$ & $0.01^{*}$ & $0.02^{* * *}$ & 0.01 \\
\hline SD & $(0.01)$ & $(0.11)$ & $(0.00)$ & $(0.00)$ & $(0.01)$ \\
\hline $\mathrm{t}$ & 1.98 & 2.17 & 1.86 & 2.84 & 0.99 \\
\hline TAN & $-0.26^{* * *}$ & $-0.13^{*}$ & $-0.10^{* *}$ & 0.05 & -0.02 \\
\hline SD & $(0.09)$ & $(0.08)$ & $(0.04)$ & $(0.05)$ & $(0.07)$ \\
\hline $\mathrm{t}$ & -2.83 & -1.71 & -2.11 & 0.97 & -0.38 \\
\hline$Q$ & - & $-0.03^{* * *}$ & - & $-0.03^{* * *}$ & -0.01 \\
\hline SD & - & $(0.00)$ & - & $(0.00)$ & $(0.00)$ \\
\hline $\mathrm{t}$ & - & -4.98 & - & -5.04 & -1.14 \\
\hline CAP & $-0.28^{* * *}$ & $-0.27^{* * *}$ & $-0.11^{* *}$ & 0.06 & $-0.33^{* * *}$ \\
\hline SD & (0.09) & $(0.08)$ & $(0.04)$ & $(0.04)$ & $(0.11)$ \\
\hline $\mathrm{t}$ & -3.11 & -3.35 & -2.47 & 1.38 & -2.87 \\
\hline $\mathrm{BF}$ & $-0.04^{* *}$ & $-0.07^{* * *}$ & $-0.02^{* *}$ & $-0.05^{* * *}$ & $-0.02^{* *}$ \\
\hline SD & $(0.02)$ & $(0.01)$ & $(0.01)$ & $(0.01)$ & $(0.01)$ \\
\hline $\mathrm{t}$ & -2.00 & -5.43 & -1.97 & -5.09 & -2.20 \\
\hline $\mathrm{APC}$ & -0.01 & $0.15^{* * *}$ & 0.00 & $0.10^{* *}$ & 0.07 \\
\hline SD & $(0.07)$ & $(0.05)$ & $(0.03)$ & $(0.04)$ & $(0.05)$ \\
\hline $\mathrm{t}$ & -0.17 & 2.71 & -0.12 & 2.41 & 1.31 \\
\hline Constant & $-0.50^{*}$ & -0.14 & -0.25 & $-0.35^{* *}$ & -0.21 \\
\hline SD & $(0.28)$ & $(0.20)$ & $(0.14)$ & $(0.14)$ & $(0.21)$ \\
\hline $\mathrm{t}$ & -1.74 & -0.72 & -1.77 & -2.53 & -1.02 \\
\hline Sector FE & Yes & Yes & Yes & Yes & Yes \\
\hline Time FE & Yes & Yes & Yes & Yes & Yes \\
\hline $\mathrm{R}^{2}$ & 0.24 & 0.49 & 0.22 & 0.56 & 0.43 \\
\hline
\end{tabular}

Note. In the header, $\mathrm{n}$ is the number of observations; TML is the total market leverage; TBL is the total book leverage; LTML is the long-term market leverage; LTBL is the long-term book leverage; and NI is the net indebtedness. In the first column, DID is the difference-in-difference estimator (obtained by the output of the kernel propensity score match in the regressions of Table 4); SR is the systematic risk; ROE is the return on equity; PL is the size (equity); TAN represents tangibility; Q is the Tobin's Q; CAP is the capex; BF is the tax benefits; APC is the ownership structure of the major shareholder; Sector FE is the sector fixed effects; Time FE is the time fixed effects; SD expresses the standard deviation; $\mathrm{t}$ represents the $\mathrm{t}$-test; and $\mathrm{R}^{2}$ is the $\mathrm{R}$-squared. Tobin's $\mathrm{Q}$ was used only in book leverage measures. The symbols ${ }^{*},{ }^{* *}$, and ${ }^{* * *}$ indicate statistical significance at $10 \%, 5 \%$, and $1 \%$, respectively. Source: elaborated by the authors. 
Table 6. Placebo test.

\begin{tabular}{|c|c|c|c|c|c|c|c|c|c|c|}
\hline & \multicolumn{10}{|c|}{ Placebo: Event year (2014) } \\
\hline & TML & (n) & TBL & (n) & LTML & (n) & LTBL & (n) & NI & (n) \\
\hline \multicolumn{11}{|l|}{ Before } \\
\hline Treated & 0.154 & 40 & 0.518 & 124 & 0.076 & 40 & 0.273 & 124 & 0.171 & 124 \\
\hline Control & 0.101 & 28 & 0.557 & 126 & 0.060 & 28 & 0.309 & 126 & 0.175 & 126 \\
\hline Difference & 0.054 & & -0.039 & & 0.016 & & -0.036 & & -0.005 & \\
\hline SD & $(0.165)$ & & $(0.034)$ & & $(0.077)$ & & $(0.025)$ & & $(0.025)$ & \\
\hline $\mathrm{T}$ & 0.32 & & -1.15 & & 0.21 & & -1.41 & & -0.19 & \\
\hline \multicolumn{11}{|l|}{ After } \\
\hline Treated & 0.594 & 121 & 0.509 & 566 & 0.267 & 121 & 0.272 & 566 & 0.139 & 566 \\
\hline Control & 0.065 & 3 & 0.508 & 11 & 0.014 & 3 & 0.260 & 11 & 0.157 & 11 \\
\hline Difference & 0.528 & & 0.001 & & 0.252 & & 0.012 & & -0.018 & \\
\hline SD & $(0.421)$ & & $(0.077)$ & & $(0.195)$ & & $(0.058)$ & & $(0.056)$ & \\
\hline $\mathrm{T}$ & 1.26 & & 0.02 & & 1.29 & & 0.21 & & 0.33 & \\
\hline DID & 0.474 & & 0.040 & & 0.236 & & 0.048 & & -0.014 & \\
\hline SD & $(0.452)$ & & $(0.084)$ & & $(0.210)$ & & $(0.063)$ & & $(0.062)$ & \\
\hline $\mathrm{T}$ & 1.05 & & 0.48 & & 1.12 & & 0.76 & & 0.22 & \\
\hline
\end{tabular}

Note. In the header, $\mathrm{n}$ is the number of observations; TML is the total market leverage; TBL is the total book leverage; LTML is the long-term market leverage; LTBL is the long-term book leverage; and NI is the net indebtedness. In the first column, DID is the difference-in-difference estimator; SD expresses the standard deviation; and t represents the t-test. The regressions were estimated using kernel propensity score matching. The placebo test indicates that the difference between the coefficients before and after IFRS adoption, as well as in the DID estimator, were not statistically significant, showing our model's internal validity. The covariates used are equity (PL), ownership structure of the major shareholder (APC), capex (CAP), tax benefits (BF), tangibility (TAN), beta (SR), and sector. Tobin's $\mathrm{Q}$ and return on equity (ROE) were excluded because it reduced considerably the number of iterations, which would make the estimation unfeasible. No variable presented significance less than or equal to $10 \%$. Source: elaborated by the authors.

\section{CONCLUDING REMARKS}

This study examines the effect of IFRS adoption on the capital structure of publicly traded Brazilian companies by comparing companies that adhered to these standards following their mandatory establishment by law (Regular level and Level 1) with firms that already adhered to IFRS before the law (Novo Mercado and Level 2 tiers). A difference-in-difference estimator was the basis of our empirical approach, using the IFRS adoption law to design an experiment in which we controlled for observed and unobserved company heterogeneity. IFRS adoption was used as a shock to analyze two groups of firms, one affected by the law (treatment group) and another not affected by it (control group).

Our preliminary results showed an increase in market leverage (TML and LTML) for companies affected by the mandatory IFRS, confirming our first hypothesis and suggesting that an increase in transparency of accounting information brought about by IFRS led to a reduction of asymmetric information between investors, shareholders, and stakeholders. These results highlight the importance of information disclosure in financing policy, indicating that IFRS triggered greater interest from foreign investors and analysts (George, Li, \& Schvakumar, 2016), aiding in a more effective investor decision-making process if compared to previous accounting standards (Figlioli, Lemes, \& Lima, 2017).

By using the kernel propensity score match to reduce the selection bias, we were able to compare companies affected by the mandatory adoption of IFRS and companies already adapted to the international disclosure standards as they are listed in B3 special tiers. We found statistical difference-in-difference coefficients for market measures, both total (TML) and long-term (LTML) leverage and also for net indebtedness. This statistical significance of DID emphasizes that, although companies from both groups changed their capital structure, especially companies affected by the shock, they continued to differ in terms of financing policy. In sum, the differences between the groups in the DID analysis over the analyzed period were influenced by the greater effect on market leverage of companies that adhered to IFRS and on the net indebtedness for companies already adhering previously to IFRS. Finally, we confirmed the pecking order theory assumptions for most of the covariates. 
In sum, in this paper we provide insights related to the Brazilian market environment, which is characterized by low access to corporate debt and weak financial development. The transition to IFRS in Brazil may require a learning process, for both companies and information users. Similar to Funchal and Monte-Mor (2016), the results provide insights to policymakers of underdeveloped economies interested in credit market expansion.

Our results contribute to the literature, showing the beneficial effects of issuing information using a globally accepted standard on the financing policy of companies in emerging countries, where companies face severe difficulties to access credit. Another contribution is related to the empirical strategy, by the use of difference-in-difference, which allowed an appropriate design to deal with problems related to endogeneity.

The limitation of this paper is that although IFRS became mandatory for the statements presented at the end of their adaptation period, the results obtained may be partially skewed by the fact that some Brazilian companies, even after this period, still showed low levels of compliance with the disclosure requirements, providing possible endogeneity problems. Future studies should investigate more interventions.

\section{REFERENCES}

Akerlof, G. A. (1970). The market for "lemons": Quality uncertainty and the market mechanism. The Quarterly Journal of Economics, 84(3) 488-500. https://doi.org/10.2307/1879431

Arping, S., \& Sautner, Z. (2010). Corporate governance and leverage: Evidencefromanatural experiment. FinanceResearchLetters, 7(2), 127-134. https://doi.org/10.1016/j.frl.2010.02.003

Axelson, U., Jenkinson, T., Strömberg, P., \& Weisbach, M. S. (2013). Borrow cheap, buy high? The determinants of leverage and pricing in buyouts. The Journal of Finance, 68(6), 2223-2267. https://doi.org/10.1111/jofi.12082

Barth, M. E., Konchitchki, Y., \& Landsman, W. R. (2013). Cost of capital and financial statement transparency. Journal of Accounting and Economics, 55(2-3), 206-224. https://doi.org/10.1016/j.jacceco.2013.01.004

Braga, R. N. (2017). Effects of IFRS adoption on tax avoidance. Revista Contabilidade \& Finanças, 28(75), 407-424. https://doi.org/10.1590/1808-057×201704680

Brüggemann, U., Hitz, J.-M., \& Sellhorn, T. (2013). Intended and unintended consequences of mandatory IFRS adoption: A review of extant evidence and suggestions for future research. European Accounting Review, 22(1), 1-37. https://doi.org/10.1080/09638180.2012.718487

Campos, A. L. S., \& Nakamura, W. T. (2015). Rebalanceamento da estrutura de capital: Endividamento setorial e folga financeira. RevistadeAdministração Contemporânea, 19(spe), 20-37. https://doi.org/10.1590/1982-7849rac20151789
Catapan, A., \& Colauto, R. D. (2015). Governança corporativa: Uma análise de sua relação com o desempenho econômicofinanceiro de empresas cotadas no Brasil nos anos de 2010-2012. Contaduría y Administración, 59(3), 137-164. https://doi.org/10.1016/S0186-1042(14)71268-9

Chung, K. H., \& Pruitt, S. W. (1994). A simple approximation of Tobin's Q. Financial Management, 23(3), 70-74. https://doi.org/10.2307/3665623

Colombo, J. A., \& Caldeira, J. F. (2018). The role of taxes and the interdependence among corporate financial policies: Evidence from a natural experiment. Journal of Corporate Finance, 50, 402-423. https://doi.org/10.1016/j.jcorpfin.2017.09.007

Correia, T. de S., Costa, I. L. de S., \& Lucena, W. G. L. (2017). O impacto da governança corporativa: Conselho de administração, estrutura de propriedade e controle e as informaçóes socioambientais nas companhias abertas. Teoria e Prática em Administração, 7(2) 156-182. https://doi.org/10.21714/2238-104X2017v7i2-33171

Cova, C. J. G. (2008). A adoção das IFRS no Brasil e o fortalecimento das boas práticas de governança. Revista Pensar Contábil, 10(42), 22-30. Retrieved from http://www.atena.org.br/ revista/ojs-2.2.3-08/index.php/pensarcontabil/article/ view/89

Daske, H., Hail, L., Leuz, C., \& Verdi, R. (2013). Adopting a label: Heterogeneity in the economic consequences around IAS/ IFRS adoptions. Journal of Accounting Research, 51(3), 495-547. https://doi.org/10.1111/1475-679X.12005 
DeAngelo, H., \& Roll, R. (2015). How stable are corporate capital structures? The Journal of Finance, 70(1), 373-418. https://doi.org/10.1111/jofi.12163

Devos, E., Rahman, S., \& Tsang, D. (2017). Debt covenants and the speed of capital structure adjustment. Journal of Corporate Finance, 45, 1-18. https://doi.org/10.1016/j.jcorpfin.2017.04.008

Figlioli, B., Lemes, S., \& Lima, F. G. (2017). IFRS, synchronicity, and financial crisis: The dynamics of accounting information for the Brazilian capital market. Revista Contabilidade e Finanças, 28(75), 326-343. https://doi.org/10.1590/1808-057x201704450

Florou, A., \& Kosi, U. (2015). Does mandatory IFRS adoption facilitate debt financing? Review of Accounting Studies, 20(4), 1407-1456. Retrieved from https://www. springerprofessional.de/en/does-mandatory-ifrs-adoptionfacilitate-debt-financing/10878178

Frank, M. Z., \& Goyal, V. K. (2009). Capital structure decisions: Which factors are reliably important? Financial Management, 38(1), 1-37. https://doi.org/10.1111/j.1755-053X.2009.01026.x

Funchal, B., \& Monte-Mor, D. S. (2016). Corporate governance and credit access in Brazil: The Sarbanes-Oxley act as a natural experiment. Corporate Governance: An International Review, 24(5), 528-547. https://doi.org/10.1111/corg.12151

Gatsios, R. C., Silva, J. M., Ambrozini, M. A., Assaf Neto, A., \& Lima, F. G. (2016). Impact of adopting IFRS standard on the equity cost of Brazilian open capital companies. RAM. Revista de Administração da Mackenzie, 17(4), 85-108. https://doi.org/10.1590/1678-69712016/administracao. v17n4p84-107

George, E.T.D.,Li, X., \&Shivakumar,L. (2016). A review of theIFRS adoption literature. Review of Accounting Studies, 21(3), 898-1004. https://doi.org/10.1007/s11142-016-9363-1

Gertler, P. J., Martinez, S., Premand, P., Rawlings, L. B., \& Vermeersch, C. M. (2016). Impact evaluation in practice. Washington, D.C.: The World Bank.

Ghio,A., \&Verona, R.(2015).AccountingharmonizationintheBRIC countries: A common path? Accounting Forum, 39(2), 121 139. https://doi.org/10.1016/j.accfor.2015.02.001

Graham, J. R., Leary, M. T., \& Roberts, M. R. (2015). A century of capital structure: The leveraging of corporate America. Journal of Financial Economics, 118(3), 658-683. https://doi.org/10.1016/j.jfineco.2014.08.005

Kieschnick, R., \& Moussawi, R. (2018). Firm age, corporate governance, and capital structure choices. Journal of Corporate Finance, 48, 597-614. https://doi.org/10.1016/j.jcorpfin.2017.12.011

Kraus, A., \& Litzenberger, R. H. (1973). A statepreference model of optimal financial leverage. The Journal of Finance, 28(4), 911-922. https://doi.org/10.1111/j.1540-6261.1973.tb01415.x

La Porta, R., Lopez-de-Silanes, F., \& Shleifer, A. (1999). Corporate ownership around the world. The Journal of Finance, 54(2), 471-517. https://doi.org/10.1111/0022-1082.00115
Lee, E., Walker, M. \& Christensen, H. B. (2010). Mandating IFRS: Its impact on the cost of equity capital in Europe [ACCA Research Report No. 105]. London: Certified Accountants Educational Trust.

Lemmon, M. L., Roberts, M. R., \& Zender, J. F. (2008). Back to the beginning: Persistence and the cross-section of corporate capital structure. The Journal of Finance, 63(4), 1575-1608. https://doi.org/10.1111/j.1540-6261.2008.01369.x

Leuven, E., \& Sianesi, B. (2014). PSMATCH2: Stata module to perform full Mahalanobis and propensity score matching, common support graphing, and covariate imbalance testing. Boston, MA: Statistical Software Components, Boston College Department of Economics.

Li, S. (2010). Does mandatory adoption of international financial reporting standards in the European Union reduce the cost of equity capital? Accounting Review, 85(2), 607-636. https://doi.org/10.2308/accr.2010.85.2.607

Locan, T. R., \& Caldeira, J. F. (2014). Estrutura de capital, liquidez de caixa e valor da empresa: Estudo de empresas brasileiras cotadas em bolsa. Revista Contabilidade \& Finanças-USP, 25(64), 46-59. https://doi.org/10.1590/S1519-70772014000100005

Lourenço, I. C., \& Branco, M. C. (2015). A governança corporativa e o efeito da adoção das IFRS: $\mathrm{O}$ caso brasileiro. Revista Universo Contábil, 11(1), 157-172. https://doi.org/10.4270/ruc.2015108

Marques, M. T., Nakao, S. H., \& Costa, P. S. (2017). Booktax differences and capital structure. RAM - Revista de Administração da Mackenzie, 18(6), 177-200. https://doi.org/10.1590/1678-69712017/administracao. v18n6p177-200

Meyer, B. D. (1995). Natural and quasi-experiments in economics. Journal of Business \& Economics Statistics, 13(2), 151-161. https://doi.org/10.1080/07350015.1995.10524589

Modigliani, F., \& Miller, M. H. (1958). The cost of capital, corporate finance and the theory of investment. The American Economic Review, 48(3) 261-297. Retrieved from https://www.jstor.org/stable/1809766

Moscariello, N., Skerratt, L., \& Pizzo, M. (2014). Mandatory IFRS adoption and the cost of debt in Italy and UK. Accounting and Business Research, 44(1), 63-82. https://doi.org/10.1080/00014788.2013.867402

Moura, A. A. F. de., \& Coelho, A. C. D. (2016). Impact of changes in accounting standards in debt ratios of firms: Evidence in Brazil. Brazilian Business Review, 13(5), $27-$ 50. https://doi.org/10.15728/bbr.2016.13.5.2

Myers, S. C. (1984). The capital structure puzzle. The Journal of Finance, 39(3), 574-592. https://doi.org/10.1111/j.1540-6261.1984.tb03646.x

Myers, S. C., \& Majluf, N. S. (1984). Corporate financing and investment decisions when firms have information that investors do not have. Journal of Financial Economics, 13(2), 187-221. https://doi.org/10.1016/0304-405X(84)90023-0 
Nakao, S. H., \& Gray, S. J. (2018). The impact of IFRS in Brazil: The legacy of mandatory book-tax conformity. Australian Accounting Review, 28(4), 482-495. https://doi.org/10.1111/auar.12223

Nnadi, M., \& Soobaroyen, T. (2015). International financial reporting standard and foreign direct investment: The case of Africa. Advances in Accounting, 31(2), 228-238. https://doi.org/10.1016/j.adiac.2015.09.007

Naranjo, P., Saavedra, D., \& Verdi, R.S. (2014). Financial reporting regulation and financing decisions. Social Sciences Research Network. https://doi.org/10.2139/ssrn.2147838

Pires, C. O., \& Decourt, R. F. (2015). The impacts of the final phase of transition to IFRS in Brazil. Revista Brasileira de Gestão de Negócios, 17(54), 736-750. https://doi.org/10.7819/rbgn.v17i54.1475

Rajan, R. G., \& Zingales, L. (1995). What do we know about capital structure? Some evidence from international data. The Journal of Finance, 50(5), 1421-1460. https://doi.org/10.1111/j.1540-6261.1995.tb05184.x

Roberts, M. R., \& Whited, T. M. (2013). Endogeneity in empirical corporate finance. In G.M. Constantinides, M. Harris, R. M. Stulz (Eds.), Handbook of the economics of finance (Vol. 2, pp. 493-572). Amsterdam: North Holland.

Sampaio, J., Gallucci, H., Silva, V. A. B., \& Schiozer R. (2020). Mandatory IFRS adoption, corporate governance, and firm value. Revista de Administração de Empresas, 60(4), 284-298. https://doi.org/10.1590/S0034-759020200405

Santos, M. A., Fávero, L. P. L., \& Distadio, L. F. (2016). Adoption of the international financial reporting standards (IFRS) on companies' financing structure in emerging economies. Finance Research Letters, 16, 179-189. https://doi.org/10.1016/j.frl.2015.11.002
Scholtz, H. D. (2014). Is systematic risk diversifiable? Presentation of a portfolio model that eliminates systematic risk. Social Science Research Network. https://doi.org/10.2139/ssrn.2533943

Silva, R. L. M., \& Nardi, P. C. C. (2014, August). A adoção completa das IFRS no Brasil reduz o custo de capital próprio? Anais da Associação Nacional dos Programas de Pós-Graduaçáo em Ciências Contábeis, Rio de Janeiro, RJ, Brazil, 8. Retrieved from http://anpcont.org.br/pdf/2014/CUE343.pdf

Silva, R. L. M., \& Nardi, P. C. C. (2017). Full adoption of IFRS in Brazil: Earnings quality and the cost of equity capital. Research in International Business and Finance, 42, $1057-$ 1073. https://doi.org/10.1016/j.ribaf.2017.07.041

Sonza, I. B., \& Kloeckner, G. O. (2014). Governança em estruturas proprietárias concentradas: Novas evidências para o Brasil. Revista de Administração, 49(2), 322-338. https://doi.org/10.5700/rausp1149

Tarantin, W. T., Junior, \& Valle, M. R. (2015). Estrutura de capital: $\mathrm{O}$ papel das fontes de financiamento nas quais companhias abertas brasileiras se baseiam. Revista Contabilidade \& Finança, 26(69), 331-344. https://doi.org/10.1590/1808-057x201512130

Vancin D., Kirch, G., Perlin, M. \& Mastella, M. (2019, July). The Impact of Board Gender-Diversity in Brazilian Firms Performance and Risk. In: Encontro Brasileiro de Finanças, Rio de Janeiro, RJ, Brasil, 19.

Vig, V. (2013). Access to collateral and corporate debt structure: Evidence from a natural experiment. The Journal of Finance, 68(3), 881-928. https://doi.org/10.1111/jofi.12020

Villa, J. M. (2016). Diff: Simplifying the estimation of differencein-differences treatment effects. The Stata Journal, 16(1), 52-71. https://doi.org/10.1177/1536867X1601600108 


\section{Authorship}

\section{Pâmela Amado Tristáo*}

Universidade Federal do Rio Grande, Instituto de Ciências Econômicas, Administrativas e Contábeis, Rio Grande, RS, Brazil.

Av. Itália, s/n, Km 8, Carreiros, Rio Grande, RS, Brazil.

E-mail address: pamelamado@hotmail.com

(1) https://orcid.org/0000-0002-8408-6942

\section{Igor Bernardi Sonza}

Universidade Federal de Santa Maria, Centro de Ciências Sociais e Humanas, Departamento de Ciências Administrativas, Santa Maria, RS, Brazil.

Av. Roraima, no 1000, Camobi, 97105-340, Santa Maria, RS, Brazil.

E-mail address: igorsonza@gmail.com

(1) https://orcid.org/0000-0001-5403-3279

* Corresponding Author

\section{Funding}

The authors reported that there is no financial support for the research in this article.

\section{Plagiarism Check}

The RAC maintains the practice of submitting all documents approved for publication to the plagiarism check, using specific tools, e.g.: iThenticate.

\section{Peer Review Method}

This content was evaluated using the double-blind peer review process. The disclosure of the reviewers' information on the first page, as well as the Peer Review Report, is made only after concluding the evaluation process, and with the voluntary consent of the respective reviewers and authors.

\section{Authors' Contributions}

$1^{\text {st }}$ author: conceptualization (equal); data curation (equal); formal analysis (equal); funding acquisition (equal); investigation (equal); methodology (equal); resources (equal); software (equal); supervision (equal); validation (equal); visualization (equal); writing-original draft (equal); writing-review \& editing (equal).

$2^{\text {nd }}$ author: conceptualization (equal); data curation (equal); formal analysis (equal); funding acquisition (equal); investigation (equal); methodology (equal); project administration (equal); resources (equal); software (equal); supervision (equal); validation (equal); visualization (equal); writing-original draft (supporting); writing-review \& editing (supporting).

\section{Conflict of Interests}

The authors have stated that there is no conflict of interest.

\section{Copyrights}

RAC owns the copyright to this content.

\section{Data Availability}

All data and materials were made publicly available through the Harvard Dataverse and can be accessed at:

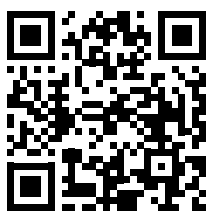

Pâmela Amado Tristáo; Igor Bernardi Sonza, 2020, "Replication Data for: Increase in Leverage Driven by International Financial Reporting Standards Adoption", Harvard Dataverse, V1. https://doi.org/10.7910/DVN/P8PXU9

RAC encourages data sharing but, in compliance with ethical principles, it does not demand the disclosure of any means of identifying research subjects, preserving the privacy of research subjects. The practice of open data is to enable the reproducibility of results, and to ensure the unrestricted transparency of the results of the published research, without requiring the identity of research subjects. 


\section{APPENDIX 1}

Table A1. Descriptive statistics for covariates.

\begin{tabular}{|c|c|c|c|c|c|c|c|c|c|c|c|c|c|c|}
\hline \multicolumn{15}{|c|}{ Treatment group } \\
\hline \multicolumn{5}{|c|}{ Before IFRS } & \multicolumn{10}{|c|}{ After IFRS } \\
\hline Var. & (n) & Mean & Med. & Min. & Max. & SD & $(\mathrm{n})$ & Mean & Med. & Min. & Max. & SD & $\mathrm{t}$ & \\
\hline ROE & 634 & 0.08 & 0.10 & -0.90 & 0.82 & 0.33 & 605 & 0.04 & 0.08 & -0.90 & 0.82 & 0.30 & 5.20 & $* * *$ \\
\hline $\mathrm{TA}^{1}$ & 636 & 15.60 & 1.57 & 0.01 & $1.01^{2}$ & 72.90 & 605 & 18.80 & 1.56 & 11.00 & 586.00 & 71.3 & -1.00 & \\
\hline $\mathrm{PL}^{1}$ & 636 & 5.67 & 0.63 & 0.01 & 273.00 & 25.80 & 605 & 9.16 & 0.69 & 4.12 & 429.00 & 42.00 & -1.26 & \\
\hline $\mathrm{R}^{1}$ & 634 & 8.65 & 0.86 & -1.41 & 546.00 & 44.00 & 605 & 9.35 & 0.64 & 0.00 & 419.00 & 45.60 & -0.65 & \\
\hline FCL & 636 & -0.25 & -0.23 & -0.85 & 0.09 & 0.23 & 605 & -0.20 & -0.15 & -0.85 & 0.09 & 0.26 & -3.55 & $* * *$ \\
\hline Q & 129 & 2.34 & 1.72 & 0.26 & 14.13 & 2.41 & 129 & 1.85 & 1.21 & 0.25 & 14.13 & 2.38 & 0.80 & \\
\hline TAN & 636 & 0.30 & 0.31 & 0.00 & 0.77 & 0.23 & 605 & 0.23 & 0.18 & 0.00 & 0.77 & 0.24 & 6.94 & $* * *$ \\
\hline LMA & 423 & 11.57 & 11.69 & 7.05 & 15.49 & 2.29 & 428 & 11.84 & 12.03 & 7.05 & 15.49 & 2.34 & -0.52 & \\
\hline CAP & 636 & 0.07 & 0.00 & 0.00 & 0.66 & 0.17 & 605 & 0.07 & 0.00 & 0.00 & 0.66 & 0.19 & -2.03 & $* *$ \\
\hline $\mathrm{BF}$ & 634 & -0.57 & -0.44 & -8.06 & 2.24 & 1.80 & 605 & -0.35 & -0.39 & -8.06 & 2.24 & 1.45 & -1.94 & $* *$ \\
\hline SR & 455 & 0.67 & 0.67 & -0.99 & 2.20 & 0.81 & 424 & 0.57 & 0.59 & -0.99 & 2.20 & 0.72 & 1.43 & $*$ \\
\hline APC & 671 & 0.61 & 0.59 & 0.15 & 0.99 & 0.27 & 768 & 0.60 & 0.58 & 0.15 & 0.99 & 0.28 & 1.74 & $* *$ \\
\hline TPAC & 671 & 0.79 & 0.85 & 0.34 & 1.00 & 0.19 & 768 & 0.77 & 0.81 & 0.34 & 1.00 & 0.21 & 2.54 & $* * *$ \\
\hline CPAC & 671 & 0.84 & 0.89 & 0.42 & 1.00 & 0.16 & 768 & 0.81 & 0.87 & 0.42 & 1.00 & 0.18 & 3.23 & $* * *$ \\
\hline \multicolumn{15}{|c|}{ Control Group } \\
\hline \multicolumn{5}{|c|}{ Before IFRS } & \multicolumn{10}{|c|}{ After IFRS } \\
\hline Var. & (n) & Mean & Med & Min & Max & SD & $(\mathrm{n})$ & Mean & Med & Min & $\operatorname{Max}$ & SD & $\mathrm{t}$ & \\
\hline ROE & 286 & 0.10 & 0.10 & -0.90 & 0.82 & 0.25 & 352 & 0.11 & 0.11 & -0.90 & 0.82 & 0.21 & 2.40 & $* * *$ \\
\hline TA & 286 & 6.15 & 2.88 & 0.04 & 68.30 & 8.51 & 352 & 7.58 & 4.03 & 0.10 & 65.20 & 9.78 & -2.42 & $* * *$ \\
\hline PL & 286 & 2.56 & 1.19 & 0.00 & 31.70 & 4.43 & 352 & 3.11 & 1.67 & 0.02 & 29.70 & 4.60 & -1.69 & $* *$ \\
\hline $\mathrm{R}$ & 286 & 3.34 & 1.28 & 0.00 & 55.20 & 5.75 & 352 & 4.26 & 1.69 & 0.00 & 96.30 & 9.05 & -1.64 & $*$ \\
\hline FCL & 286 & -0.17 & -0.11 & -0.85 & 0.09 & 0.22 & 352 & -0.11 & -0.03 & -0.80 & 0.09 & 0.22 & -3.82 & $* * *$ \\
\hline Q & 72 & 2.50 & 2.17 & 0.25 & 9.97 & 1.95 & 94 & 1.96 & 1.37 & 0.25 & 10.97 & 1.84 & 2.70 & $* * *$ \\
\hline TAN & 286 & 0.25 & 0.19 & 0.00 & 0.77 & 0.23 & 352 & 0.19 & 0.09 & 0.00 & 0.77 & 0.21 & 4.54 & $* * *$ \\
\hline LMA & 220 & 12.75 & 12.95 & 7.05 & 15.49 & 1.58 & 291 & 13.03 & 13.23 & 7.95 & 15.49 & 1.42 & -1.46 & $*$ \\
\hline CAP & 285 & 0.01 & 0.00 & 0.00 & 0.66 & 0.06 & 352 & 0.05 & 0.00 & 0.00 & 0.66 & 0.16 & -4.31 & $* * *$ \\
\hline $\mathrm{BF}$ & 286 & -0.25 & -0.06 & -8.06 & 2.24 & 1.40 & 352 & -0.33 & -0.36 & -4.82 & 2.24 & 1.09 & 3.53 & $* * *$ \\
\hline SR & 272 & 0.98 & 0.97 & -0.99 & 2.20 & 0.63 & 353 & 0.92 & 0.88 & -0.99 & 2.20 & 0.57 & 1.78 & $* *$ \\
\hline APC & 140 & 0.58 & 0.52 & 0.15 & 0.99 & 0.27 & 228 & 0.52 & 0.48 & 0.15 & 0.99 & 0.28 & 2.83 & $* * *$ \\
\hline TPAC & 140 & 0.76 & 0.79 & 0.34 & 1.00 & 0.21 & 228 & 0.71 & 0.73 & 0.34 & 1.00 & 0.23 & 2.86 & $* * *$ \\
\hline CPAC & 137 & 0.80 & 0.86 & 0.42 & 1.00 & 0.18 & 225 & 0.75 & 0.77 & 0.42 & 1.00 & 0.20 & 2.51 & $* * *$ \\
\hline
\end{tabular}

Note. Treated group is formed by companies affected by IFRS and control group by companies not affected by IFRS in the sample. In the header, Var. indicates the variables; $\mathrm{n}$ is the number of observations; Mean is the average value; Med. indicates the median; Min. and Max. represent the minimum and maximum values; SD is the standard deviation; and trepresents the t-test. In the first column, ROE is the return on equity; TA is the total assets; PL is the equity; R represents net sales; FCL is the free cash flow; $\mathrm{Q}$ is the Tobin's Q; TAN represents tangibility; LMA is the change in log assets; CAP is the capex; BF is the tax benefits; SR is the systematic risk; APC, TPAC, and CPAC are the ownership structure of the major, three and five major shareholders, respectively; ${ }^{1}$ in billion; ${ }^{2}$ in trillion. The symbols ${ }^{*},{ }^{* *}$, and ${ }^{* * *}$ indicate statistical significance at $10 \%$, $5 \%$, and $1 \%$, respectively. Source: elaborated by the authors. 